\title{
CORPORATE GOVERNANCE AS AN INNOVATIVE BOOSTER: A LITERATURE REVISION
}

\author{
GOVERNANÇA CORPORATIVA COMO PROPULSORA DA INOVAÇÃO: UMA REVISÃO DE \\ LITERATURA
}

\section{EL GOBIERNO CORPORATIVO COMO MOTOR DE INNOVACIÓN: UNA REVISIÓN DE LA LITERATURA}

\author{
Fernanda Kempner-Moreira ${ }^{1}$ \\ Patrícia de Sá Freire ${ }^{2}$ \\ Júlio César Zilli ${ }^{3}$
}

Cite as - American Psychological Association (APA)

Kempner-Moreira, F., Freire, P. S., \& Zilli, J. C. (2020, Sept./Dec.). Corporate governance as an innovative booster: a literature revision. International Journal of Innovation - IJI, São Paulo, 8(3), 356-372.

https://doi.org/10.5585/iji.v8i3.15037.

\begin{abstract}
Objective of the study: The purpose of this article was to identify the elements to be considered for boosting innovation by the corporate governances, though.

Methodology/approach: It is a literature review, based on the Scopus database, relating the constructs corporate governance and innovation, generating 435 documents in total, using 253 documents imported into the Mendeley application and resulting in 26 documents with effective contributions on governance and innovation.

Originality/relevance: The study differs in that it relates corporate governance to the innovation of organizations.

Main results: The results show that corporate governance has a positive influence on the innovation of organizations, but it is necessary to adapt to the context of each organization and the innovation characteristics of the sector. The first element to be considered is the presence of innovation in the organization's strategy and policies, followed by the commitment, strategic posture and competence of the board for innovation, adaptation of the governance structure, effective management of key competencies for innovation, investment in research and development, financing of innovation and technology, control over investments in innovation and management of risks inherent to innovation.

Theoretical/methodological contributions: The study contributes to the advancement of knowledge by presenting the elements to be considered to boost innovation by corporate governance.
\end{abstract}

Social/management contributions: It is also indicated that there is an effective management of its key competences for innovation, mapping them and ensuring that the governance

\footnotetext{
${ }^{1}$ Mestra em Administração, Universidade Federal de Santa Catarina - UFSC. Florianópolis, Santa Catarina - Brasil. kempnereletrica@ hotmail.com

${ }^{2}$ Doutora em Engenharia e Gestão do Conhecimento - EGC, Universidade Federal de Santa Catarina - UFSC. Florianópolis, Santa Catarina - Brasil. patriciadesafreire@ gmail.com

${ }^{3}$ Mestre em Desenvolvimento Socioeconômico - PPGDS, Universidade do Extremo Sul Catarinense - UNESC. Criciúma, Santa Catarina - Brasil. zilli42@ hotmail.com
} 
structure promotes an environment conducive to their development, in addition to investments in $R \& D$ and financing for innovation and technology.

Keywords: Governance. Corporate governance. Innovation. Literature Revision.

\section{Resumo}

Objetivo do estudo: $O$ objetivo deste artigo foi identificar elementos a serem considerados para que a governança corporativa impulsione a inovação.

Metodologia/abordagem: Trata-se de uma revisão da literatura, a partir da base de dados Scopus, relacionando os constructos governança corporativa e inovação, gerando 435 documentos no total, utilizando-se 253 documentos importados para o aplicativo Mendeley e resultando em 26 documentos com contribuições efetivas sobre os temas governança e inovação.

Originalidade/relevância: $\mathrm{O}$ estudo diferencia-se por relacionar a governança corporativa sobre a inovação das organizações.

Principais resultados: Os resultados apontam que a governança corporativa tem influência positiva sobre a inovação das organizações, mas é necessária a adaptação ao contexto de cada organização e das características de inovação do setor. O primeiro elemento a ser considerado é a presença da inovação na estratégia e nas políticas da organização, seguida do comprometimento, postura estratégica e competência do conselho para a inovação, adaptação da estrutura de governança, gestão efetiva das competências-chave para a inovação, investimento em pesquisa e desenvolvimento, financiamento da inovação e da tecnologia, controle sobre investimentos em inovação e gestão dos riscos inerentes à inovação. Contribuições teóricas/metodológicas: $\mathrm{O}$ estudo contribui para o avanço do conhecimento ao apresentar os elementos a serem considerados para impulsionar a inovação pelas governanças corporativas.

Contribuições sociais/gerenciais: Também é indicado que haja uma gestão eficaz das suas competências-chave para a inovação, mapeando-as e garantindo que a estrutura de governança promova um ambiente propício ao seu desenvolvimento, além dos investimentos em $P \& D$ e o financiamento para inovação e tecnologia.

Palavras-chave: Governança. Governança corporativa. Inovação. Revisão da Literatura.

\section{Resumen}

Objetivo del estudio: El objetivo de este artículo fue identificar los elementos a considerar para que el gobierno corporativo impulse la innovación.

Metodología/enfoque: Se trata de una revisión de la literatura, basada en la base de datos Scopus, que relaciona los constructos de gobierno corporativo e innovación, generando 435 documentos en total, utilizando 253 documentos importados a la aplicación Mendeley y dando como resultado 26 documentos. con contribuciones efectivas sobre gobernanza e innovación.

Originalidad/relevancia: El estudio se diferencia en que relaciona el gobierno corporativo con la innovación de las organizaciones.

Principales resultados: Los resultados muestran que el gobierno corporativo tiene una influencia positiva en la innovación de las organizaciones, pero es necesario adaptarse al contexto de cada organización y las características de innovación del sector. El primer elemento a considerar es la presencia de innovación en la estrategia y políticas de la organización, seguido del compromiso, postura estratégica y competencia del consejo para la innovación, adecuación de la estructura de gobierno, gestión efectiva de competencias clave para la innovación, inversión. en investigación y desarrollo, financiación de la innovación y 
tecnología, control de las inversiones en innovación y gestión de riesgos inherentes a la innovación.

Aportes teórico-metodológicos: El estudio contribuye al avance del conocimiento al presentar los elementos a considerar para impulsar la innovación mediante el gobierno corporativo.

Aportes sociales/gerenciales: También se indica que existe una gestión efectiva de sus competencias clave para la innovación, mapeándolas y asegurando que la estructura de gobierno promueva un entorno propicio para su desarrollo, además de inversiones en I + D y financiamiento para la innovación. y Tecnología.

Palabras-clave: Gobernanza. Gobierno corporativo. Innovación. Revision de literatura.

\section{Introduction}

The discussion about governance has been evocated by the public and private sectors, due to the need for readjustment of the control structures. In the quest for overcoming discrepancies between the stakeholders and the company's structure, some monitoring and incentive mechanisms have emerged, in order to grant the alignment of these actors to the organizational objectives. Despite the initial concept of governance being associated to the equity and to the rights between the involved parties, practice shows that the term became synonymous of controlling and monitoring the actions of the management, in order to accomplish the desired results, though.

The governance perception as an important element invaded the public and private organizations, giving origin to the terms Corporate Governance, Public Governance, and Public Corporate Governance, each one with its particularities, but with the very same basic principle of monitoring and controlling to achieve the organizations' results. This means that the current governance elements are based upon control mechanisms, in order to avoid conflicts between the stakeholders and to promote positive results for the organizations.

Another important element for the organizations is the concern with the innovation, boosted through technological evolution and to the increase of global competition, which forces them to a dynamism such, that can only be contemplated by an innovative culture (Damanpour, Szbat \& Evan, 1989), after all, the ability to change and to readapt is essential for survival (Trott, 2012, p.4) and through the maintenance of their strategic positions, though the renovation of their products and services (Tidd, Bessant \& Pavit, 2008).

Innovation requires a flexible and communicative environment, valuing the cooperative culture. Among the aspects that inhibit innovation, bureaucratic and excessive controlled environments must be mentioned, as they discourage innovative and creative ideas, though. In 
this context comes the following question: If the Corporate Governance main target is to monitor and control and these elements inhibit innovation, then what elements must be considered by the Corporate Governance to boost innovation? This question is the base to the objective of this article; there is, to identify the elements to be considered by the Corporate Governance to boost the innovation.

This article comprises this introduction, where the context, the question of the research and the main targets are shown; the theoretic referential of the Corporate Governance and Innovation concepts; the ranking methodology used in this article; analysis and results based on selected articles chosen and, finally, the final considerations.

\section{Corporate governance}

The term governance became of very special importance among public and private management, permeating the organizational strategies. For Rosenau (1922), the governance is the result of interaction between various players, with the objective of, in a coordinated manner, to promote common goods or to establish public order, guiding the individuals to achieve their goals.

Fischer (1996) corroborates that governance, is a relationship between the parties involved, promoting negotiations and determining the roles to be played by every agent in the process. Rhodes (1996), on the other hand, highlights that the term has several meanings, such as minimum State, corporate governance, new public administration, good governance practices, and self-organized networks, among others.

The idea that the governance is a network of relationship between several players involved, also supported by Mayntz (1999), Gilsing (2000), Humprhey and Schmitz (2002) Cassiolato e Szapiro (2003), Campos e Callefi (2009), McGee (2010), Rover (2011) and Oliveira, Carvalho and Corrêa (2013). The concept of governance is kind of diffuse and may be used on several contexts, such as corporate governance for the business management, public governance to inhibit bribes and corruption of public employees, among others (Alves, 2001).

Literature in general spreads the concept that Corporate Governance comes from the World Bank, for which, governance is defined as an exercise of authority, control, management and the power of government, a term associated with "good governance" (World Bank, 1992). It is understood that governance is the element that provides the management the guidelines to solve their conflicts, to execute their tasks, simultaneously to the monitoring of their own actions, though. 
For the IBCG (2015, p.20), Corporate Governance is a system, from which the companies and other organizations are managed, monitored and encouraged, involving the relationship between the owners, a board of directors, supervisory and control bodies and the remaining parties involved. By the means of transparency principles, equity, accountability, and corporate responsibility, the target is to assure efficient and value-added management to the organizations (IBGC, 2017).

For the OCED (2004), the corporate governance is responsible for the integrity of the corporations, which means taking care of the political and structural structure in all levels, promoting health care and economic stability. It is noted that the definitions of corporate governance lie in monitoring and control as a way to grant good organizational performance (Cadbury, 1992; Onado, 2000). The definition of the concept of corporate governance does not emphasize cooperation and interaction, as the governance concept used to praise.

Such concern with the control became more relevant within modern organizations, where the management and control are made separately (Siffert Filho,1998). The separation between organizational management and property brought the so-called conflict of interests, as not often one party's interests are the same as the other party, though. This way, the corporate governance came to create monitoring and controlling mechanisms in the actions of the management, as a way to preserve the alignment with the interest of the shareholders (Malacrida \& Yamamoto, 2006).

The reinforcement in controlling the corporate governance practices somehow removes power from the management, diminishing their liberty action, and at the same time sharing responsibilities and are supported by the experience and knowledge of the board (Fontes Filho \& Picolin, 2008). The eagerness in monitoring and controlling the actions of the executives, according to the definitions of the corporate governance, lost the link between several actors forming the common good network, emphasizing more the controlling and monitoring mechanisms, which in a certain manner, presumes a stiffening of the management actions.

\subsection{Innovation}

The innovation is shown by several authors as a matter of survival and maintenance of the competitivity (Lee, Smith \& Greimm, 2003; Tidd Bessant \& Pavitt, 2008; Trott, 2012; Rhéaume \& Gardoni, 2016).

Simantob e Lipp (2003) present different innovation concepts from several authors. For Schumpeter it is the opening of a new market; for Prahalad is the adoption of new technologies 
that increases competitivity; for Gundling it is a new successfully implemented idea with economic results; for Hamel it is a strategic and continuous re-inventing process of the own business and the creation of new concepts; for Bell and Pavit, innovation is a process of organizational learning; for Drucker it is the attributions of new capacities to the resources, in order to generate wealth.

A classical innovation concept is given by the OECD (2004), where an innovation means the implementation of a product, good or service, new or considerably improved, or a process, or a new marketing method, or still, a new organizational method in the business practices, in the workplace or in external relationships.

Innovation can be seen as a process or a result, where a part of its theoretical concept assumes the body of a technical invention and it is commercially explored (Trott, 2012). As such, if the economic commercialization does not occur, it is not an innovation but invention instead, as the innovation main target is to increase the organizational value, in order to grant the competitiveness (Schumpeter, 1997). Innovation is also the result of new knowledge, created during the innovation process, to allow the understanding of how the innovation process occurred.

That is the essence of the innovation process, which defines innovation as a result (Quintanae, Casselman, Reich \& Nylund, 2011; Rhéaume \& Gardoni, 2016). Innovation is, therefore, a knowledge-based process (Tidd, Bessant \& Pavitt, 2008). In spite of having different concepts, there is a consensus that the innovation process envelopes investments, time, uncertainties and risks.

Innovation may reach four business areas, known as the 4 P's of the invention: Product, Process, Place, and Paradigm. It may also impact in two different ways: by Incremental Innovation (by doing better what is already done) and Radical Innovation (by doing differently what has been done) (Tidd, Bessant \& Pavitt, 2008). The novelty level may also be classified as Discontinued Innovation (the creative destruction of Schumpeter) and Disruptive Innovation (the new markets of Christensen) (Hang, Neo \& Chai, 2006).

Some scientific studies relate the creativity to the innovation (Bruno-Faria, Veiga \& Macedo, 2008). Gondim, Loiola, Morais, Dutra, Rovira, Rodrigues, Lima and Mourão (2015) shows an interesting study about how the workers define creativity and innovation. Results vouch that workers understand creativity and innovation as important elements in an organizational context, whether for the re-arrangement of ideas (creativity), whether through the improvement of the processes and their results (innovation). 
Furthermore, in this process, the management must play a role to promote both, creativity and innovation, whether by strategic planning means or by actions of structures, processes and working conditions, to name a few. It is also necessary a leadership training, in order to promote a less critical and more stimulating atmosphere to boost the collaborative learning and to promote self-confidence amongst individuals, in order to comprehend that all can effectively contribute for creativity and, for that matter, for innovation (Gondim, et al, 2015).

In order to stimulate innovation, the authors suggest the employees to have the freedom to innovate, the support from the management, a proper atmosphere for the expression of creativity, incentives and bonuses, a proper physical environment, organizational values that stimulates the experimenting, opening, acceptance and support to the new ideas, receptivity, commitment and taking risks (Alencar, 1995; Correia, Dellagnelo, 2004; Parolin \& Albuquerque, 2004; Andrade, Tolfo \& Silva, 2006).

As inhibiting factors for the innovation, we can mention the excess of bureaucracy, lack of freedom, authoritarianism, stability, rigidness, control, routine, behavior patterns, extremely formal relationships, power and domination, distrust, organizational flux, excess of service, resources availability, pressure for results, intransigence and lack of team spirit (Alencar, 1995; Correia, Dellagnelo, 2004; Parolin \& Albuquerque, 2004; Andrade, Tolfo \& Silva, 2006). It must be noted that a good share of these elements is already inserted in the concepts and mechanisms of Corporate Governance, though.

\section{Methodological procedures}

This study is meant to be theoretical research, using the revision of the literature research technique (Botelho, Cunha e Macedo, 2011). The search has been made in the Scopus data basis, on May 22nd, 2018, using the searching protocol "corporate governance" AND "innovation" on titles, resumes and key-words of scientific articles, generating 435 documents in total.

As an inclusion criterion, there were used articles in Portuguese and English languages though (of the author's domain), which came to a total of 253 documents that were imported to the Mendeley app., is this a conscious limitation of this study.

Out of these documents, 5 articles did not have summaries available. After the reading of the remaining 248 articles, 39 have shown a relationship with the purpose of this study. Two of these articles, entitled as "Corporate Governance and the Innovation System in France 1985- 
2000" and "Governance Structure and the Creativity and Innovation Process" were from paid accesses, thus being discarded, with 37 articles remaining for extensive reading, though.

Such procedure refined the data, as out of the 37 documents read, only 26 brought effective contributions on the governance and innovation subjects, being discarded the remaining 11 articles. A thorough overview of the validated articles is presented in the following session.

\section{Analysis and results}

Amongst the 248 resulting from the systematic research, the main authors are Andrew Tylecote with 07 articles, Hsueh-Liang Wu with 04 articles and Jamel Chouaibi with 03 articles. Among the journals, Corporate Ownership and Control first appeared, followed by Corporate Governance, Research Policy, Journal of Business Ethics and Journal of Business Research, respectively. There are, of the 26 articles selected for the complete reading and considered suitable for this research, 05 authored by Tylecote, 03 by Wu and 01 by Chouaibi, which are in the general listing, and 03 by Zhang, an author who does not appear in the Scopus basis analyzes. From the list of 03 journals were published in Research Policy, 01 in Corporate Governance and 01 in the Journal of Business Research.

The analysis of the articles showed that the studies consider corporate governance as an important factor for innovation. For Cantista and Tylecote (2008), corporate governance has "decisive influence" on the "level of enterprise innovation". Belloc (2012) brings an interesting link between corporate governance and innovation, listing the various dimensions of corporate governance, the possible channels of relationship with innovation and the authors considered the reference in the literature, revealing that there is a positive relationship between the constructs. It also emphasizes that corporate governance "affects the way individuals integrate their human and physical resources into the company" for the sake of innovation (Belloc, 2012, 837).

The 26 articles considered valid for the current analysis corroborate with Belloc (2012) when demonstrating relevant relations between corporate governance and innovation. Most of the studies present statistical analyzes to prove their hypothesis that governance positively influences innovation. "To improve business innovation and R \& D capabilities, they need to improve their corporate governance" (Dong \& Gou, 2010, p.188). However, the authors argue that their studies cannot be generalized since most refer to specific sectors or comparative 
studies between countries. Despite this limitation of studies, it is observed that everyone perceives governance as positive for innovation and organizational development.

Al-Mannaei and Hamdan (2016: 23) consider that "the application of corporate governance supports the creation of innovation and provides a work environment, which encourages innovation because each person knows the extent of their power", that is, governance creates elements that foster innovation in organizations. But governance, by itself, does not guarantee innovation. Drejer (2008) stresses that corporate governance effectively covers operational effectiveness, but does not always consider innovation in its strategies, which leads to the perception that a supplement is needed that fosters innovation.

In their first paper on the subject, Tylecote and Conesa (1999) argue that governance is important for innovation, but must be tailored to each sector, as the characteristics of innovation are different and depend on a context that should be considered by governance. "Effective corporate governance of innovative firms requires an ability to deal with three types of problems, which can be labeled innovation, visibility and appropriateness" (Tylecote \& Conesa, 1999: 47). Ouedraogo (2008) presents two dimensions for corporate governance to manage the innovation process: "a structure more adaptable to innovation and effective management of key competencies" (page 58).

Years later, Tylecote and Ramirez (2006, p. 162) present four challenges imposed by innovation for governance: "The novelty of innovation; The need for reconfiguration; The visibility of innovation; The adequacy of innovation ". These elements are closely related to the need to analyze the context of innovation. In their publications of 2005 and 2007, the author emphasizes the importance of financing and corporate governance in organizational results, especially related to innovation and technology (Visintin, Ozgen, Tylecote, \& Handscombe, 2005, and Tylecote, 2007).

Wu's articles date from 2007 and 2008 and seek to clarify how governance cooperates with innovation. The 2007 article presents the governance conditions that lead to managerial decisions in risk-taking that foster innovation: board commitment, power relations, strategic posture, and board competence (Wu \& Lee, 2007). In 2008, Wu (2008a) points out that executives are risk-averse, and corporate governance can be a resource used by shareholders to monitor and minimize such fear), and that "companies in governance regimes have contexts that seem essential to foster risk-management preparation and thus lead to better performance of innovation "(Wu, 2008, p.150). 
Miozzo and Dewick (2002, p. 990) conducted a study with 17 European contractors and empirically pointed out that "particular characteristics of the corporate governance structure of contractors support different types of innovation at the company level", that is to say, by adjusting corporate governance is innovate at different levels. It is worth mentioning that Miozzo and Dewick (2002) is the most cited article, with 83 citations, until the date of the research.

The main metric used to evaluate innovation is the number of patents. Chiang, Leeb, and Anandarajanc (2013) argue that patent production is positively impacted by more effective corporate governance, and also increases corporate values. This influence is highlighted by other authors as a greater investment in research and development (R \& D), which would lead to increased innovation (Wu, 2008a; Dong \& Gou, 2010; Zhang, Chen \& Feng, 2014; Hasan, Raymar \& Song Shapiro, Tang, Wang. \& Zhang, 2015). However, this same influence was not characterized when the analysis involves sales growth (Chiang, Leeb \& Anandarajanc, 2013). The factors that must be considered by governance so that innovation is propelled are identified in Table 1 with the studied papers.

Table 1 - Elements to be considered by corporate governance for innovation

\begin{tabular}{|c|c|}
\hline Elements & Authors \\
\hline $\begin{array}{l}\text { Innovation contemplated in the organization's } \\
\text { strategy and policies. }\end{array}$ & $\begin{array}{l}\text { Wu \& Lee (2007); Wu (2008b); Cantista \& Tylecote } \\
\text { (2008); Chouaibi, Affes \& Boujelbene (2009); Talke, } \\
\text { Salomo \& Rost (2010); Baird, Furukawa, Rahman \& } \\
\text { Schneller (2014). }\end{array}$ \\
\hline $\begin{array}{l}\text { Commitment, strategic position and competence of } \\
\text { the board for innovation }\end{array}$ & Wu e Lee (2007). \\
\hline $\begin{array}{l}\text { Adapt the governance structure to the innovation } \\
\text { context in which the organization is inserted }\end{array}$ & $\begin{array}{l}\text { Tylecote \& Conesa (1999); Miozzo \& Dewick (2002); } \\
\text { Tylecote \& Ramirez (2006); Ouedraogo (2008). }\end{array}$ \\
\hline $\begin{array}{l}\text { Effective management of key competences for } \\
\text { innovation. }\end{array}$ & Ouedraogo (2008). \\
\hline Investment in research and development (R \& D). & $\begin{array}{l}\text { Wu (2008a); Dong \& Gou (2010); Chiang, Leeb, } \\
\text { Anandarajanc (2013); Zhang, Chen \& Feng (2014); } \\
\text { Hasan, Raymar \& Song (2015); Shapiro, Tang, Wang. } \\
\text { \& Zhang (2015). }\end{array}$ \\
\hline Financing focused on innovation and technology. & Visintin, Ozgen, Tylecote, \& Handscombe (2005). \\
\hline Control over investments in innovation. & $\begin{array}{l}\text { Miozzo \& Dewick (2002); Wu (2008a); Belloc } \\
\text { (2012); Prencipe (2016); Gu \& Zhang (2017). }\end{array}$ \\
\hline Managing the risks inherent in innovation.. & Wu (2008a); Wu (2008b); Zhang (2017). \\
\hline
\end{tabular}

Source: Authors' own elaboration based on research data.

Miozzo \& Dewich (2002) argue that innovation depends on the adequacy of corporate governance. As a result, such elements were identified from the authors mentioned above, mentioning the need to incorporate innovation in the organization's strategies and policies, as well as the commitment and competence of the board for innovation. In fact, adapting the 
governance structure to the context of innovation in which the organization is inserted, enhances the management of its key competences. Another important point is the availability of investment in $\mathrm{R} \& \mathrm{D}$, control over investments and the management of risks inherent to innovation.

Some articles analyze governance not only at the corporate level, but also public governance, arguing that without public governance organizations are hampered in their innovation strategies (Visintin, Ozgen, Tylecote, \& Handscombe, 2005; Sapra, Subramanian \& Subramanian, 2014, Hasan, Raymar \& Song, 2015). Atanassov (2013) demonstrates that governance mechanisms can even soften the negative effects that control imposed by public governance can cause.

\section{Final considerations}

The concept of corporate governance emerged with the idea of cooperation and interaction among stakeholders as a way to guarantee the achievement of common goals. However, what is perceived is that the term became synonymous with monitoring and controlling the actions of managers. Its principles are permeated by transparency and accountability, which is also necessary, but it is observed that the initial essence of the concept of governance, that is, the network of collaboration for the common good, ended up in second place.

The review of the literature shows that corporate governance exerts a positive influence on the innovation of organizations. The studies argue that an organization that has the mechanisms of corporate governance becomes more "reliable" to attract investment in innovation. However, Miozzo and Dewich (2002) argue that innovation depends on the adequacy of corporate governance, that is, some elements need to be considered in order for innovation to be effectively fostered.

This study found that corporate governance by itself does not promote innovation. It needs to be addressed in the organization's strategy and policies, as well as an adaptation to the innovation context in which the organization is inserted. Allied to this, it is necessary aboard effectively committed to the innovation of the organization, from a strategic and competent position, under penalty of the efforts are considerably reduced. Based on these results, the study contributes to the advancement of knowledge, when it presents the elements to be considered for boosting innovation by the corporate governances, though. 
In order to achieve competitive results in terms of innovation, it is also indicated that there is effective management of its key competencies for innovation, mapping them and ensuring that the governance structure promotes an environment conducive to its development.

Other elements to be considered are investments in R \& D and financing for innovation and technology. And when talking about investments and financing, it is up to corporate governance to create mechanisms to monitor and control investments, ensuring that they are applied consciously and effectively, and ultimately managing the risks inherent in innovation.

The study presents as a limiting factor the research carried out in a single database (SCOPUS) and that only articles in English and Portuguese were used. Thus, it is suggested that the study be extended to other databases, also adding studies developed in theses, books and non-indexed articles.

\section{Acknowledgments}

Federal University of Santa Catarina (UFSC), through the Postgraduate Program in Engineering and Knowledge Management (EGC / UFSC), and the Research Laboratory for Integration Engineering and Knowledge Governance (LabENGIN).

University Scholarship Program of Santa Catarina (UNIEDU / Postgraduate).

Universidade do Extremo Sul Catarinense (UNESC), through the Research Groups Support Program, and the Management and Strategy in International Business Research Group (GENINT / UNESC).

\section{References}

Al-Mannaei, H. M. H. \& Hamdan, A. M. M. (2016). Corporate governance and innovation: Evidence from bahrain bourse. Corporate Board: Role, Duties and Composition, 12(1).

Alencar, E.L.S. (1995). Desenvolvendo a criatividade nas organizações: o desafio da inovação. Rev. adm. empres., São Paulo, 35(6), 6-11.

Alencar, E.L.S. (1998). Promovendo um ambiente favorável à criatividade nas organizações. Rev. adm. empres., São Paulo, 38(2), 18-25.

Alves, L.E.S. (2001). Governança e cidadania empresarial. Rev. adm. empres., São Paulo, 41(4), 78-86.

Andrade, S.P.C., Tolfo, S.R. \& Silva, E.M. (2006). A cultura organizacional e a expressão da criatividade no produto moda vestuário infantil: um estudo de caso. In: In: Anais do Encontro da Associação Nacional dos Programas de Pós-graduação e Pesquisa em Administração (EnANPAD). Rio de Janeiro: ANPAD. 
Atanassov, J. (2013). Do Hostile Takeovers Stifle Innovation? Evidence from Antitakeover Legislation and Corporate Patenting. Journal of Finance, 68(3).

Baird, A., Furukawa, M.F., Rahman, B. \& Schneller, E.S. (2014) Corporate governance and the adoption of health information technology within integrated delivery systems. Health Care Management Review, 39(3).

Belloc, F. (2012). Corporate governance and innovation: A survey. Journal of Economic Surveys, 26(5).

Botelho, L.L.R., Cunha, C.C.A. \& Macedo, M. (2011). O método da revisão integrativa nos estudos organizacionais. Gestão e Sociedade, Belo Horizonte, 5(11), 121-136.

Bruno-Faria, M. F., Veiga, H. M. S. \& Macedo, L. F. (2008). Criatividade nas organizações: análise da produção científica nacional em periódicos e livros de Administração e de Psicologia. Revista Psicologia: Organizações e Trabalho, Florianópolis, 8(1), 142-163.

Cadbury Report. (1992). The report of the Committee on the Financial Aspects of Corporate Governance. London: The Committee on the Financial Aspects of Corporate Governance and Gee and Co.

Campos, A.C. \& Callefi, P. (2009). Arranjos Produtivos Locais de confecção no Paraná: uma análise comparativa. Informe Gepec (Impresso), Toledo, 13(2), 85-103.

Cantista, I. \& Tylecote, A. (2008). Industrial innovation, corporate governance and suppliercustomer relationships. Journal of Manufacturing Technology Management, 19(5).

Cassiolato, J.E. \& Szapiro, M. (2003). Uma caracterização de arranjos produtivos locais de micro e pequenas empresas. In: Lastres H.M.M, Cassiolato, J.E \& Maciel M.L. (orgs.). Pequena Empresa: Cooperação e Desenvolvimento Local. Rio de Janeiro: Dumará.

Chiang, S., Lee, P. \& Anandarajan, A. (2013). Corporate governance and innovative success: An examination of the moderating influence of a firm's life cycle stage. Innovation: Management, Policy and Practice, 15(4).

Chouaibi, J., Affes, H. \& Boujelbene, Y. (2010). Characteristics of the board of directors and involvement in innovation activities: a cognitive perspective. International Journal of Managerial and Financial Accounting, 2(3), 240-255.

Correia, G. S. \& Dellagnelo, E. H. L. (2004). Avaliação do potencial da estrutura para o desenvolvimento da criatividade em uma indústria catarinense. In: Anais do Encontro da Associação Nacional dos Programas de Pós-Graduação e Pesquisa em Administração (EnANPAD). Curitiba: ANPAD.

Damanpour F., Szabat, K.A. \& Evan, W.M. (1989). The relationship between types of innovation and organizational performance. Journal Management Studies, 26(6), 587-601.

Dong, J. \& Gou, Y.-N. (2010). Corporate governance structure, managerial discretion, and the R\&amp;D investment in China. International Review of Economics and Finance, 19(2). 
Drejer, A. (2008). Are you innovative enough? International Journal of Innovation and Learning, 5(1).

Fischer, T. (1996). Gestão contemporânea, cidades estratégicas: aprendendo com fragmentos e reconfigurações do local. In: Fischer, T. (org.). Gestão estratégica: cidades estratégicas e organizações local. Rio de Janeiro: FGV.

Fontes Filho, J.R. \& Picolin, L.M. (2008, Dez). Governança corporativa em empresas estatais: avanços, propostas e limitações. Rev. Adm. Pública, Rio de Janeiro, 42(6), 1163-1188.

Gilsing, V. (2000). Cluster governance: how clusters can adapt and renew over time. Copenhagen: Department of Business Studies.

Gondim, S.M.G., Loiola, E., Morais, F.A.de, Dutra, S.C.C., Rovira, D.P., Rodrígues, M., Lima, D.C.R.de, \& Mourão, L. (2015). Creativity and Innovation as Defined by Worker. REAd. Revista Eletrônica de Administração (Porto Alegre), 21(3), 549-575.

Gu, Y. \& Zhang, L. (2017). The impact of the Sarbanes-Oxley Act on corporate innovation. Journal of Economics and Business, 90, 17-30.

Hang, C.C., Neo, K.B. \& Chai, K.H. (2006). Discontinuous technological innovations: a review of its categorization. In: Management of Innovation and Technology, IEEE International Conference on, 253-257.

Hasan, I., Raymar, S. \& Song, L. (2015). Effects of corporate and country governance on R\&D investment: Evidence from emerging markets. Singapore Economic Review, 60(1).

Humphrey, J. \& Schmitz, H. (2002). Developing country firms in the world economy: Governance and Upgrad-ing in Global Value Chains. Institut für Entwicklung und Frieden der Gerhard-Mercator-Universität Duisburg.

Instituto Brasileiro de Governança Corporativa [IBGC]. Governança Corporativa: Princípios Básicos. Recuperado em 05 de janeiro, 2017, do http://www.ibgc.org.br/index.php/governanca/governanca-corporativa/principios-basicos.

Instituto Brasileiro de Governança Corporativa [IBGC]. (2015). Código das melhores práticas de governança corporativa. São Paulo: IBGC.

Lee, H., Smith, K.G. \& Grimm, C.M. (2003). The effect of new product radicality and scope on the extent and speed of innovation diffusion. Journal of Management, 29, 753-768.

Malacrida, M.J.C. \& Yamamoto, M.M. (2006). Governança corporativa: nível de evidenciação das informações e sua relação com a volatilidade das ações do Ibovespa. Rev. contab. finanç., São Paulo, 17, 65-79.

Mayntz, R. (1994). La teoria della governance: sfide e prospettive. Rivista italiana di scienza politica, n. Bulmer 1994, 3-21. 
Mcgee, T. (2010). Construindo uma governança urbana colaborativa para as regiões metropolitanas no Brasil e no Canadá. In: Castro, E., Wojciechowski, M.J. (org.). Inclusão, Colaboração e Governança Urbana. Belo Horizonte: PUC Minas.

Miozzo, M. \& Dewick, P. (2002). Building competitive advantage: Innovation and corporate governance in European construction. Research Policy, 31(6), 989-1008.

OECD. (2004). Principles of Corporate Governance. OECD Publications Service, 1-178.

Oliveira, A. G., Carvalho, H.A. \& Corrêa, D. P. (2013). Governança pública e governabilidade: accountability e disclosure possibilitadas pela contabilidade aplicada ao setor público como instrumento de sustentabilidade do estado. Revista de Educação e Pesquisa em Contabilidade, Brasília, 7(1), 91-104.

Onado, M. (2000). Mercati e intermediari finanziari, "Il Mulino", Bologna.

Ouedraogo, A. (2008). Managing innovation, human resource and corporate governance in technological SMEs: Lessons from case studies in Canada. Problems and Perspectives in Management, 6(3).

Parolin, S.R.H. \& Albuquerque, L.G. (2004). A criatividade, a inovação e a competência dos gestores: suas relações com o comprometimento organizacional. In: Anais do Encontro Anual da Anpad. Rio de Janeiro: ANPAD.

Prencipe, A. (2016). Board composition and innovation in university spin-offs. Evidence from the Italian context. Journal of Technology Management and Innovation, 11(3).

Quintane, E., Casselman, R.M., Reiche, B.R. and Nylund, P.A. (2011) Innovation as a Knowledge-Based Outcome. Journal of Knowledge Management, 15, 928-947.

Rhéaume, L. \& Gardoni, M. (2015). Strategy-making for innovation management and the development of corporate universities. International Journal on Interactive Design and Manufacturing (IJIDeM), 10(1), 73-84.

Rhodes, R.A.W. (1996). The New Governance: Governing Without Government. Political Studies. University of Newcastle-upon-Tyne. 44, 652-667.

Rosenau, J. (1992). Governance, order and change in world politics. In: Rosenau, J. \& Czempiel, O. (eds) Governance Without Government: order and change in world politics. Cambridge: Cambridge University Press, 1-29.

Rover, O.J. (2011, Jan-Abr). Obstáculos e exigências para a governança regional. Revista Brasileira de Gestão e Desenvolvimento Regional, Taubaté, 7(1), 130-152.

Sapra, H., Subramanian, A. \& Subramanian, K.V. (2014). Corporate governance and innovation: Theory and evidence. Journal of Financial and Quantitative Analysis, 49(4).

Shapiro, D., Tang, Y, Wang, M. \& Zhang, W. (2015). The effects of corporate governance and ownership on the innovation performance of Chinese SMEs. Journal of Chinese Economic and Business Studies, 13(4), 311-335. 
Schumpeter, J. A. Teoria do desenvolvimento econômico: uma investigação sobre lucros, capital, crédito, juro e ciclo econômico. São Paulo: Nova Cultural, 1997.

Siffert Filho, N. F. (1998, Jul). Governança corporativa: padrões internacionais e evidências empíricas no Brasil nos anos 90. Revista do BNDES. Rio de Janeiro. 5(9), 123-46.

Simantob, M. \& Lippi, R.C. (2003). Guia Valor Econômico de inovação nas empresas. São Paulo: Globo.

Talke, K., Salomo, S. \& Rost, K. (2010). How top management team diversity affects innovativeness and performance via the strategic choice to focus on innovation fields. Research Policy, 39(7).

Tidd, J., Bessant, J. \& Pavitt, K. (2008). Gestão da Inovação. 3. ed. Porto Alegre: Bookman.

Trott, P. (2012). Gestão da inovação e desenvolvimento de novos produtos. 4. ed. Porto Alegre: Bookman.

Tylecote, A. (2007). The role of finance and corporate governance in national systems of innovation. Organization Studies, 28(10).

Tylecote, A. \& Conesa, E. (1999). Corporate governance, innovation systems and industrial performance. Industry and Innovation, 6(1).

Tylecote, A.\& Ramirez, P. (2006). Corporate governance and innovation: The UK compared with the US and "insider" economies. Research Policy, 35(1).

Visintin, F., Ozgen, B, Tylecote, A. \& Handscombe, R. (2005). Italian success and British survival: Case studies of corporate governance and innovation in a mature industry. Technovation, 25(6).

World Bank. (1992). Governance and development. Washington: World Bank.

Wu, H.-L. (2008a). How do board-CEO relationships influence the performance of new product introduction? Moving from single to interdependent explanations. Corporate Governance, 16(2).

Wu, H.-L. (2008b). When does internal governance make firms innovative? Journal of Business Research, 61(2).

Wu, H.-L. \& Lee, C.-Y. (2007). The effects of board competence on operational innovation: Tests of universal, contingency and configurational models. International Journal of Technology Management, 39(3-4).

Zhang, Q., Chen, L. \& Feng. (2014). T. Mediation or Moderation? The Role of R\&amp;D Investment in the Relationship between Corporate Governance and Firm Performance: Empirical Evidence from the Chinese IT Industry. Corporate Governance (Oxford), 22(6). 